\title{
No Museum is an Island: Ethnography beyond Methodological Containerism
}

\author{
Sharon Macdonald*, Christine Gerbich**, Margareta von Oswald***
}

\begin{abstract}
:
This article addresses the question of how to go beyond the conceptualization of museums as islands in museum ethnography without losing the ethnographic depth and insights that such research can provide. Discussing existing ethnographic research in museums, the ethnographic turn in organization studies, and methodological innovation that seeks to go beyond bounded locations in anthropology, we offer a new museum methodology that retains ethnography's capacity to grasp the often overlooked workings of organizational life - such as the informal relations, uncodified activities, chance events and feelings - while also avoiding 'methodological containerism', that is, the taking of the museum as an organization for granted. We then present a project design for a multi-sited, multi-linked, multi-researcher ethnography to respond to this; together with its specific realization as the Making Differences project currently underway on Berlin's Museum Island. Drawing on three sub-projects of this large ethnographyconcerned with exhibition-making in the Museum of Islamic Art, in the Ethnological Museum in preparation for the Humboldt Forum (a high profile and contested cultural development due to open in 2019) and a new exhibition about Berlin, also for the Humboldt Forum - we highlight the importance of what happens beyond the 'container,' the discretion of what we even take to be the 'container', and how 'organization-ness' of various kinds is 'done' or 'achieved'. We do this in part through an analysis of organigrams at play in our research fields, showing what these variously reveal, hide and suggest. Understanding museums, and organizations more generally, in this way, we argue, brings insight both to some of the specific developments that we are analysing as well as to museum and organization studies more widely.
\end{abstract}

Key words: ethnography, museum, methodology, organization, organigram, Berlin

\section{Introduction}

In late November 2017, 'organigram' (Organigramm in German) seemed to be 'word of the week' in the Berlin museum world. Journalist Jörg Häntzschel had published an article in the widely distributed newspaper, the Süddeutsche Zeitung, about the Humboldt Forum, a new cultural and exhibition space - including displays from various museum collections - currently in the making in Berlin. As well as containing stinging criticism of what he described as a 'dizzying system of political interests' resulting in 'paralysis, intransparency and a lack of ideas', his article included an organigram, setting out 'the labyrinthine organizational structure' (see Figure 1). ${ }^{1}$ Entitled 'the consensus machine', it provided a dramatic visualization of the complexity of achieving any such agreement on the directions of the new Humboldt Forum. ${ }^{2}$

As curators involved in one part of the Humboldt Forum gathered for a meeting shortly after the article's publication, there was amused talk about the organigram - not least its name. 'What was it called? Organ... organism...? Ah yes, organigram'. The sheer act of expressing visually something that they themselves felt and partly knew but had not seen put quite like this, seemed to be a confirmation of sorts. 'Yes, the whole organization is crazily complicated'. 'Wahnsinn'-madness. At a leaving party later that week for the director of one of the museums 
to be included in the Humboldt Forum, the organigram - as well as the article's acerbic content - was a frequent topic of conversation. A few people suggested amendments (usually adding further complexity) that the organigram required, but many comments were to the effect that the article uttered an important truth, the diagrammatic depiction of the organizational situation providing visual testimony of a highly complex governance, lacking in a single authority or clear lines of accountability.

\section{Die Konsensmaschine}

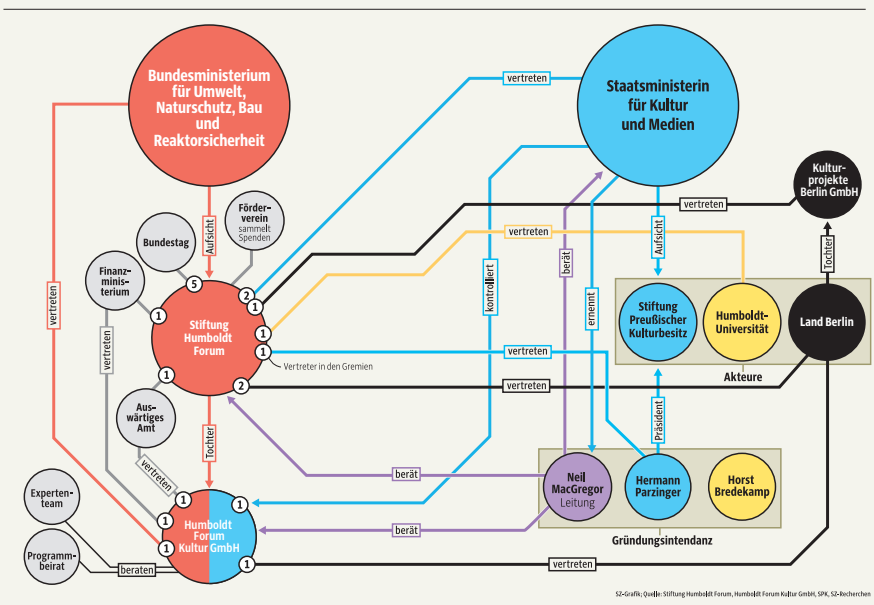

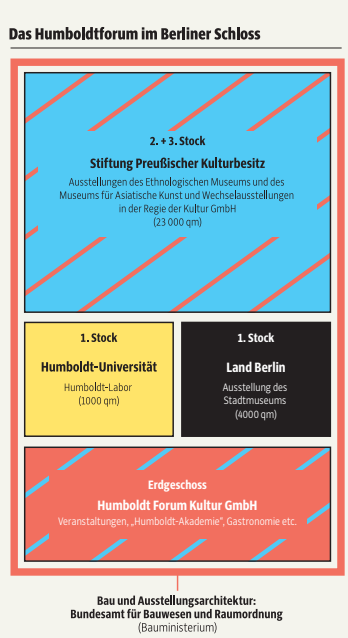

Figure 1. The Consensus Machine: Organigram of the Humboldt Forum, Berlin, in the Süddeutsche Zeitung 20.11.2017. Reproduced with permission from Süddeutsche Zeitung Grafik.

Translations. Akteure-Actors; Aufsicht-Oversight; Ausstellung des Stadtmuseums-exhibition of the City Museum; Ausstellungen des Ethnologischen Museums und des Museums für Asiatisches Kunst und Wechselausstellungen in der Regie der Kultur GmbH Exhibitions of the Ethnological Museum and the Museum of Asian Art and temporary exhibitions under the direction of Culture Ltd.; Auswärtiges Amt - Foreign Office; Bau und Ausstellungsarchitektur - building and exhibition architecture; Bauministerium - Construction Ministry; berät - advises; beraten - advised by; Berliner Schloß - Berlin City Palace; Bundesamt für Bauwesen und Raumordnung (Bauamt) - Federal Office for Construction and Planning (Planning Office); Bundesministerium für Umwelt, Naturschutz, Bau und Reaktorschutz - Federal Ministry for Environment, Nature Protection, Building and Nuclear Reactor Protection; Bundestag-German Federal Parliament; Expertenteam - team of experts; Finanzministerium - Ministry of Finance; Förderverein sammelt spenden-Friends'Association collects donations; Gastronomie - catering; Gründungsintendanz-Founding Directorship; Humboldt Forum Kultur GmbH-Humboldt Forum Culture Ltd.; kontrolliert - controlled; Kulturprojekte Berlin GmbH-Berlin Cultural Projects Ltd.; Land Berlin - Berlin federal state; Leitung - Direction; Programmbeirat-Programme advisory board; Staatsministerin für Kultur und Medien - Federal Minister for Culture and Media; Stiftung Humboldt Forum - Humboldt Forum Foundation; Stiftung Preußischer Kulturbesitz - Prussian Cultural Heritage Foundation; Stock - floor; Tochter - daughter; Veranstaltungen - events; vertreten - represented; Vertreter in den Gremien - representative in the committees.

Within organization studies and related fields of study, organigrams are diagrammatic attempts to 'represent an organization's social structure' (Hatch 2011:22). Produced by a wide range of organizations themselves, they can also be seen as part of a wider apparatus that produces organizational order; like meetings and agendas, they help to 'tame, narrow, and contain uncertainty' (Brown et al. 2017: 23). In situations of greater complexity, it has been argued (e.g. Lima 2011), visualizations become all the more important for helping to make structures or processes clearer and easier to grasp. The newspaper's Berlin Humboldt Forum 
organigram is, therefore, somewhat paradoxical, if not unique, in its deployment of a tool that usually aims at 'de-complexification' but which, in this case, serves primarily to emphasise the high degree of complexity involved.

Below, we give further attention to this and other organigrams - not just as attempted representations but also as ethnographic artefacts, which circulate within the fields we research, prompting responses and creating effects (cf. Riles 2006 on documents). By beginning with an organigram, however, our aim is not to introduce an analysis of organigrams in themselves, nor even of visualization in museums and research, important though both of these are. Rather, it is in order to launch our methodological discussion of conducting ethnographic research in awareness of organizational complexity, especially what we might call inter-, exo- and transorganizational complexity, namely that which spreads beyond a single organization ${ }^{3}$. Many, indeed possibly most, organigrams focus on structures and processes within an organization (endo-organizational) and, indeed, serve to help visualize the organization as an integrated unit - as an island. Thus, although being faced with such a complex organigram as the one in Figure 1 may not be an experience of all those who have conducted research in museums, there is no doubt that organigrams highlighting multiple organizational players, governance structures and other relationships that extend beyond the museum's walls could be constructed for the great majority of museums - if only rarely, perhaps, with quite as much complexity as in this case. Such organizations are, inevitably, entangled in multiple networks of various kinds, usually involving some degree of distributed governance.

The question, therefore, is how, as researchers, do we address this methodologically - especially when we seek to conduct in-depth research within organizations. How, in other words, do we conduct ethnographic research, and not lose the insights that such an approach can bring, in the face of the kind of complexity - and, in effect, distributed agency - expressed by the organigram? Can we still go 'behind the scenes' - to deploy a primary trope of museum ethnography - without falling into the 'methodological containerism' (cf. Winter et al. 2014; and to model a term on arguments about the risks of 'methodological nationalism'-e.g. Wimmer and Glick Schiller 2002), the seeing museums as isolated islands, that such a trope easily evokes?

To raise these questions is, in effect, to also ask what we even mean by an organization and, indeed, a museum. It is about where museums begin and end; about the extent to which they are, or should be seen as, islands; and about where we follow and also cut networks (Strathern 1996). As we discuss below, giving attention to ways in which museums may extend beyond their walls is not unprecedented, and there is much that can be learned from earlier research. Nevertheless, there is still a need for further methodological discussion of the implications of a critical focus on 'organization-ness' for ethnographic research. In particular, there is a need for the museum field, as George Marcus has argued for ethnography more generally, to find ways for 'designing fieldwork and its practices in, through and between more complex institutional orders' (2012: 431). This is what we seek to do here.

To do so, we describe the design and methods of a multi-researcher, multi-organizational ethnography of current museum and related developments in Berlin. More specifically, we draw on three ethnographic studies of exhibition-making being undertaken by the three authors of this article that are part of the larger ethnography. These three studies are of the making of an exhibition in the Museum of Islamic Art; the making of displays by the Ethnological Museum for the already mentioned Humboldt Forum; and of an exhibition about Berlin, also to be included in the Humboldt Forum. There are multiple organizational linkages, overlaps and other relationships between and across our fieldwork sites. Simply knowing these at an organigramic - structural - level, however, does not fully explain how these are experienced and produced on the ground, or the different responses to being part of the same structures. Indeed, being part of the shared structures is by no means a guarantee of interaction; and, thus, although we argue in part for a relational perspective and for recognising the fluidity and porosity of organizations (Cameron 2015), we also urge attention to non-connections and to the ways in which 'doing organizations' in practice can also limit collaboration and change.

\section{Going behind the scenes}

We have already briefly alluded to some reasons for conducting ethnographic research in museums or indeed in organizations more generally. It is useful, however, to set this out a 
little more fully before discussing how to retain the positive qualities of in-depth fieldwork within organizations while also avoiding taking organizations as an unexamined methodological container. There are various understandings of what is meant by 'ethnography', and a vast literature, which we do not wish to revisit here. In brief, however, we find helpful Daniel Miller's characterization of it as a set of methodological commitments rather than simply a method, those commitments including being in direct presence of the people involved and over enough time to be able to get a sense of what is relatively usual or unusual activity (Miller 1997:16). As such, ethnographic research can incorporate a range of methods, such as documentary analysis, but, to achieve the commitments, it almost certainly involves at least some degree - and in anthropological ethnography, usually a substantial amount - of 'deep hanging out' (Geertz 1998).

As the introduction to a recent special issue of the Journal of Organizational Ethnography pointed out, the last decade has seen a considerable increase of interest in ethnography in organization and management studies, such that some commentators speak of an ethnographic turn, even though the history of conducting ethnographic studies of organizations reaches back much further (Rouleau et al. 2014). The main reasons for increased interest are summed up well in another article in the same volume, which refers to ethnography's 'unique added value as a research method and more broadly as a methodology' (Zilber 2014: 97):

Ethnographic studies may yield indispensable insights about the social dynamics of the field, insights that cannot be discovered and analyzed otherwise. Ethnography allows us to study the 'extraordinary-in-the-ordinary' (Ybema et al., 2009, p. 2), the social processes involved in constructing and allowing for the everyday, ordinary lived experiences of people within organizational and inter-organizational spheres. It allows learning about "what "actually happens" or about "how things work"' (Watson, 2011). It enables thus a focus on the hidden, the less visible and less explicit dimensions of organizational or inter-organizational life, including emotions and power relations, thus highlighting the interplay between actors (whether individual or collective) and context (Yanow et al., 2012). (Zilber 2014: 97)

The same arguments for conducting ethnographic research can be made for museums (Bouquet 2012; Gable 2013). All, indeed, are well exemplified in the first substantial published museum ethnographies by anthropologists: Richard Handler and Eric Gable's study of Colonial Williamsburg (1997) and Tamar Katriel's of two Israeli settler museums (1997). Both showed the social processes in everyday museum work, especially of museum guides, revealing what happens in practice and the usually invisible power relations involved. In making their argument for such an ethnographic approach, Handler and Gable famously observed that most of what had thus far been written on museums had paid little attention to what actually goes on inside them (1997: 9); and they themselves showed how such attention revealed a problematic racial politics of everyday practice that was at odds with Colonial Williamsburg's public rhetoric.

In the two decades since these museum ethnographies were published, there have been many more studies employing some degree of ethnographic research, though precisely what this means varies and the number of published book-length monographs based on long-term ethnography, such as those of Handler and Gable and of Katriel, remains small. Nevertheless, primarily within shorter pieces, at least some degree of ethnographic research has been taken in a wide range of kinds of museums and covering many topics. Most ethnographies have approached the museum via their work cultures and, or particular practices, such as exhibitionmaking (Macdonald 2002; Yaneva 2012; Morgan 2013; Bunzl 2014; Franklin 2014; Shannon 2014; Bouquet 2015; Jung 2015; Kreplak 2017), conservation, archiving and digitization (Domínguez Rubio 2014; Beltrame 2015; March 2016), education and other forms of public engagement (Roberts 1997; Morse and Munro 2015; Knudsen 2016). They have looked at the ways in which publics use museums (Macdonald 2009; Bhatti 2012; Schmitt 2012; Debary and Roustan 2017; Kendzia 2017; Sabeti 2018), or at exhibitions and the representation of museums in the media (Price 2007; Torres 2011; von Bose 2016; Porsché 2017). Only a small number look at practices that explicitly cross the museum's borders or that extend its scope, such as into community work (Hendry 2005; Krmpotich and Peers 2013; Schorch et al. 2016); knowledge exchange with amateurs (Meyer 2008) or the museum's collecting practices (O'Hanlon 
1993; Förster and Stoecker 2016). Even where the boundaries are crossed, however, most ethnographies still take the museum as an organization for granted.

This is reinforced by the trope of going behind the scenes of museums. This has been deployed in a range of popular accounts of museums, including those written by museum staff (e.g. Smith 2007, Danziger 2008, Grande 2017). Within museum ethnography, it has been used by Sharon Macdonald, whose Behind the Scenes at the Science Museum (2002) draws in part on Goffman's ideas of going backstage to an area that is usually hidden. ${ }^{4}$ More recently, Matti Bunzl, in his ethnography of Chicago's Museum of Contemporary Art (MCA), articulates the power of the trope when he writes: 'Other scholars have had to content themselves with observing museums from the public galleries, thwarted, if they even tried, by institutional reluctance to grant behind-the-scenes access. I had the good fortune of being admitted into the fortress by a gutsy organization that was willing to take a chance' (2014: 7). This allowed him, he argues, to 'shed a unique light on the motivations of individuals and groups' (2014: 8).

While the behind the scenes trope works effectively as a narrative device to promise revelation of the hidden and unknown to visitors, it potentially contributes to a methodological emphasis on museums as autonomous - as island-like. Critiques of what we might call 'methodological containerism' have become widespread in anthropology as part of more thoroughgoing questioning of what constitutes, or might constitute, an ethnographic field (e.g. Gupta and Ferguson 1997). Likewise, questioning of 'methodological nationalism' - a taking for granted of the nation as the frame of study - has received considerable attention in several disciplines (e.g. Wimmer and Glick Schiller 2002).

As part of such questioning, anthropology has now for some considerable time been arguing for the importance of designing modes of conducting ethnography that allow for addressing translocal movements and flows. In STS there have been attempts to go beyond organizational boundaries (e.g. Winter et al. 2014), and in organization studies too, arguments are increasingly being voiced for developing forms of ethnography that can go 'beyond a single organization', though, as yet, well conceptualized and theorized examples are 'quite rare to find' (Zilber 2014: 97).

\section{Going beyond (behind) the scenes}

Before considering how research might be redesigned to better allow for investigation beyond a single organization, it is important to note that, despite the fact that the great majority of ethnographic research conducted in museums and in other kinds of organizations has taken a solo-organizational empirical focus, this does not mean that they were necessarily conceptualized as strongly idiographic - that is, as having relevance only to the specific cases. Rather, through their theorizing and contextualization, they seek to make broader arguments. In a robust recent instance, for example, Matti Bunzl states that his finding of the pervasiveness of financial considerations in curatorial decisions in the MCA 'is true of every museum collecting contemporary art' (2014: 83). The basis for this claim is not explicitly articulated. Nevertheless, it is implicit in his discussion of the wider global art markets in which the MCA is enmeshed.

In most cases, it is through contextualization within broader debates and developments that museum ethnographies seek to be relevant beyond their specific cases. For the most part, this is not done by claiming that the one museum is representative of others but is, rather, by seeing it as a specific response to conditions that may be more widely shared. Thus, for example, Sharon Macdonald's science museum ethnography positions itself within what she sees as a major cultural transformation in which museums, alongside other organizations, were called to public account (in developments we would now call neo-liberal) - and in which struggles in the museum showed different understandings and consequences of what this entailed. Looking at what can in part be seen as a further intensification of some of the developments that Macdonald investigated, the ethnographies of Nuala Morse and Ealasaid Munro show how deeply neo-liberal discourses are present within the local museums that they study but also how museum staff respond differently to the shared conditions through what the authors call 'progressive articulations of localism' (2015: 4).

Despite the claims for wider relevance, and although most ethnographers discuss to some extent at least the wider governance structures within which museums operate, almost 
all existing museum ethnographies take the museum as an organization as self-evident and almost all only include ethnographic research within one institution. Exceptions are Katriel (1997), Munro and Morse (2015), Mangione (2016) and Porsché (2018), which bring together at least some degree of ethnographic research in two or three museums. By comparison with other areas of anthropology, however, ethnographic innovation seeking to move beyond soloorganizationalism remains sparse.

In other areas of anthropology, there have by now been numerous innovations that seek to move beyond single site research (Falzon 2016), while retaining - to varying degrees of success - ethnographic depth. Many of these involve forms of 'following' - of objects, ideas or people as they move across multiple sites (Marcus 1998). Some of the idea of following has been taken up in museum anthropology, especially in relation to the following of objects, often drawing on the idea of object biographies (Kopytoff 1986; Basu 2011, Tythacott 2011, Förster and Stocker 2016, von Oswald and Rodatus 2017). There is, however, undoubtedly scope for further ethnographic innovation in the museum field. Rather than making suggestions about possible projects that might profitably be undertaken in the future, let us here turn to a project that has been designed in order to retain in-depth organizational ethnography while also, at the same time, enabling looking beyond a single case.

\section{Making Differences Project Design}

The project is a multi-researcher study that is currently underway in Berlin. Its broad concern is with transformations within museums and heritage formations and practices, especially as these relate to questions of social and cultural difference and diversity. How, it asks, are museums and heritage being reconfigured through changing conceptions and practices of diversity, and in relation to changing constellations of social difference (such as those resulting from postcoloniality and migration)? What changes and what remains? And with what effects? It includes focus on ethnographic museums and on museum and heritage approaches to Islam as these have been some of the most contentious and active domains in which such questions have been raised. The project is designed, however, to avoid restricting itself to these but instead to allow for exploration of how diversity and difference play out in other museum and heritage practices, such as those of 'biodiversity' in natural history museums or of 'alterity' in post-colonial art practice, thus making it possible to see where there is traffic between and across these. ${ }^{5}$

In some ways, the research design could be loosely conceptualized as following ideas of difference and diversity across various sites and practices. This, however, is too linear and thread-like a conceptualization to be able to capture a design that is more collage-like, with overlaps and discontinuities, such that even the notion of 'network' seems not quite fitting. Instead, guided by the notion of 'constellations of difference' (Fiskesjö 2007; Macdonald 2016), the research proceeds from multiple sites - offering a range of vantage points - and then seeks, from a grounded approach, to collectively explore the convergences, connections and discrepancies that emerge.

Rather than further discuss the overall project, which is still underway (it runs until 2020) and currently includes ten researchers, some of whom have only begun recently, we focus here on the work of three researchers - the authors of this article - who have been part of the project since 2015 or 2016 and who have been conducting ethnography of exhibition-making processes within relatively high profile museum developments. These three alone highlight partly shared and overlapping organizational structures through which to raise the question of museums as organizations with which this article is concerned, as well as also showing how the ethnographic perspective allows a handle on how organizations are experienced and produced in practice.

One often remarked-upon feature of ethnographic research is that it is especially likely to bring concerns to the fore that had not been anticipated. In our collective research, which entails frequent team discussion of ongoing as well as completed fieldwork, this has further dimensions in that we sometimes also find ourselves all encountering the same unanticipated event, experience or phenomenon. Moreover, something that arises in the ethnographic experience of one researcher can act as an 'attention alert', prompting others to look to see whether this is to be found in theirs too. Organigrams, largely prompted by the circulation of the one with which we began this article, were just such a case. This led us to look further at 
organigrams in and across our field sites, and to use these as points of departure for considering the institutional orders in which our sites are enmeshed.

\section{Organigrams as Suggestions}

Organigrams are visualizations of organizations that identify subsections (which may be organizations themselves) - usually depicted as circles or rectangles - and their relationships (by lines), usually of governance. Although organigrams are usually thought of as merely representative, there is considerable discretion in how they are compiled. As Deleuze writes of diagrams more generally, they can also act to 'suggest' (McCosker and Wilken 2014).

Given that the article for which the organigram of the Humboldt Forum (Figure 1) was compiled sought to suggest that consensus would be hard due to multiple sources of decision-making, the organigram does not seek to tidy up as much as do most organigrams. At the same time, however, it excludes further detail - including the kind evident from ethnography - which would make it more complicated still. In particular, it does not mention any of the museums and curatorial teams that are part of the making of the Humboldt Forum. That is, it excludes the very organizations that we had taken as locations for our fieldwork. Museums as organizations and as actors in decision-making have, in effect, been melted out of the picture. The Ethnological Museum - which is sometimes mistakenly regarded as the Humboldt Forum - and the Museum of Asian Art, whose former sites have both been closed and whose curators are busy preparing new displays for the Humboldt Forum, do not appear as such in the organigram but are, instead, subsumed under the larger organization of which they are part, namely the SPK (Stiftung Preussischer Kulturbesitz - Prussian Cultural Heritage Foundation). This, however, also includes other museums, including the Museum of Islamic Art, which are not involved in the Humboldt Forum. The Berlin exhibition does not appear as such but is distributed across several units, namely, 'Land Berlin' (the State of Berlin) - the Berlin area governance - and 'Kulturprojekte' (which literally means Cultural Projects), a non-profit cultural organization funded by the Land Berlin. Moreover, the city museums - the Stadtmuseen - with which this exhibition is strongly linked, though not formally subsumed, through sharing a director and some staff, are also absent. ${ }^{6}$

In flagging these absences, our aim is not to suggest that the organigram is faulty in not including them. Rather, the point is that what had seemed like obvious actors in the process to us - and indeed to many others, as we witness in talk outside as well as within our field sites are not necessarily seen as such and it is entirely possible to create a meaningful representation of the Humboldt Forum's organization without them. This supports our argument that we should not take museums for granted as autonomous or as the operational organizational units.

Let us here turn to another organigram, that of the State Museums of Berlin (SMB Staatliche Museen zu Berlin - Figure 2). In this, by contrast, museums are the predominant units depicted - including the Ethnological Museum (EM) and the Museum of Islamic Art (ISL). Also by contrast with the Humboldt Forum organigram, this one is very simple and tidy. In being so, it performs the usual neatening-up function of an organigram; but like the other organigram, and indeed organigrams more generally, it necessarily masks considerable complexities and makes specific suggestions. This organigram takes the conventional form of looking rather like a genealogical kinship chart - a format that itself suggests the organization as a family, with the romanticised associations of functional togetherness that this implies. ${ }^{7}$ It also depicts a rather flat hierarchy - only two layers; and lists all of the museums as equals in size and status.

These organigramic suggestions, however, belie the situation on the ground. The SMB and the SPK of which it is part (the flat hierarchy in the diagram being achieved in part by not including the SPK) are widely talked about as 'hierarchical'. This is due not least to the fact that many decisions that elsewhere would be taken at museum level are here taken by the General Directorate - which is in most cases and for most matters the budget holder rather than museums themselves. Within museum workforces there is often talk of things 'being decided above' or even 'imposed from above', the imprecise term 'above' ('von oben'), indicating that staff members are often unclear about the exact source of decisions, especially whether they come from the SMB or SPK. The presentation of the museums as equally-sized siblings hides the fact that they are rather differently sized - the EM, for example, has about twice the staff 


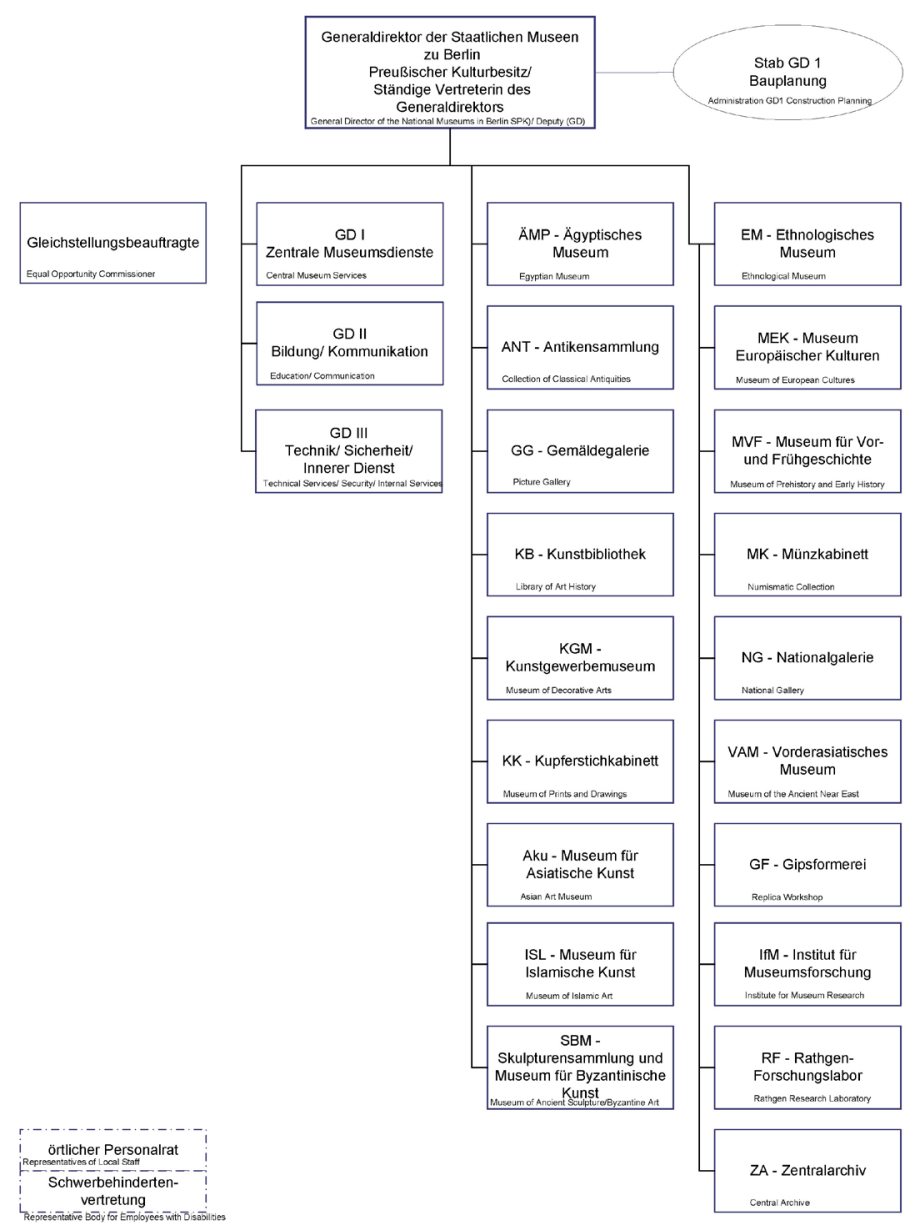

Figure 2. Organigram of the State Museums of Berlin. Dated 01.10.2013 but still current on the website in April 2018. Reproduced with the permission of the Prussian Cultural Heritage Foundation. English translations added by the authors. 
of the ISL and (until its closure in 2018) a considerably larger exhibition space. Moreover, the museums do not all stand in identical relationships to one another as the organigram suggests. For example, the ISL's permanent exhibition and part of its collections are physically located within the Pergamon Museum, together with the Vorderasiatisches Museum (Museum of the Ancient Near East) and the Antikensammlung (Collection of Classical Antiquities). The ISL's administration, however, is located a ten minute walk away from the Pergamon Museum, in the Archaeological Centre, where it shares office space and infrastructures with other institutions of SMB, including the Egyptian Museum und Papyrus Collection, the Museum of Prehistory and Early History and the Museum of the Ancient Near East.

We could continue to consider further organigrams and what they reveal, mask and suggest. The main point that we wish to make, however, is that a methodological focus on museums as containers - or islands - risks overplaying their autonomy. At the same time, they are often perceived as such in practice and, indeed, do often act as such, and this is also important for understanding the processes involved. In the next section, then, we briefly note some of the ways in which organizational processes beyond our field sites become present in ways that might not be readily evident without ethnographic fieldwork, before turning to some ways in which museums and curatorial teams come to be experienced as such by those who work within them.

\section{Beyond the Museum Walls}

Organigrams can tell us that a museum is part of a larger organization or that some of its functions - such as creating a new exhibition or undertaking educational outreach - may be distributed beyond its walls. What they don't tell us is how this works on the ground, and how these relationships are experienced in practice and with what effects.

Neither organigram, for example, tells us of the considerable and often highly important informal networks between individuals, and more occasionally groups, that can operate at all levels. Some of the newer museum directors - in networks that cross-cut the SMB and other museums - meet informally to discuss some of the difficulties that they perceive and ways of tackling them. Who instigates or participates in these-or is invited to do so-is selective, however, and this can contribute to some museum directors or other potential participants becoming, or remaining, marginalized. In the Humboldt Forum developments likewise, there are numerous meetings that happen informally or semi-formally over breakfast or dinner, sometimes even in people's homes. Again, these only involve some participants but they can nevertheless serve as significant conduits for information and lobbying, as well as building up informal coalitions of people 'we can work with'. These in turn influence exhibition content - especially in relation to filling the currently physically empty container of the Humboldt Forum itself.

Informal networking also operates at numerous other levels. The fact, for example, that the SMB's technicians work in all of the museums puts them into the position to convey information between museums. From an ethnographic perspective, we can also see how shared educational services across the SMB actually operate, with particular coalitions and individuals shaping what happens on the ground; and fieldwork also revealing otherwise invisible, but in practice quite significant, details. For example, an initially informal contact led to a member of the ISL's conservation staff who held a personal interest in educational matters becoming involved in exhibition-making, resulting in both new content and a new display format.

Ethnographic fieldwork also tells us how the wider organizational structures, such as those of the SMB and SPK are perceived and experienced by those who are part of them, especially by those lower in the pecking-order whose views are not often sought out. We already noted a tendency for the SPK and SMB to be described as hierarchical and authoritative as a 'tanker' as museum staff sometimes put it - within the museums that are part of them. They make their presence felt at local level - and in our fieldwork - through how they are talked about and how decisions made 'above' impact on the everyday work of curators and other museum staff. While sometimes this operates through the kinds of stated decisions and policies that could be charted without working ethnographically, in situ research shows how other 'institutional orders' may be perceived and experienced and in practice.

In the EM, for example, during the planning for the Humboldt Forum in 2013-2014, as 
witnessed by Margareta during her fieldwork, there was a widespread sense of disorientation, such that one new recruit described feeling 'thrown into unknown territory without a compass,' and - in some ways surprisingly given the claims of hierarchical structures - said that there were 'no structures'8. The statement was due, however, to the recruit's widely shared perception of a need to create new structures and processes to produce the new Humboldt Forum. But the comment also reflected a more long-standing perception of decision-making as distant and opaque, such that it could appear arbitrary - a phenomenon also witnessed in the ISL. This in turn contributed to there sometimes being an affective atmosphere characterized by insecurity, frustration, cynicism and stress. The particular organizational structures were thus not only cognitively recognized but were also felt; and while the emotions themselves were partly described by museum staff members' verbal descriptions, they were also manifest through gestures, facial expressions, body postures, and tone of voice, that could only be witnessed through fieldwork and, indeed, the co-feeling of the deeply involved ethnographer.

As well as showing how organizational structures 'beyond' our immediate sites were experienced locally, our fieldwork also led us beyond the museum walls or the offices of the exhibition teams in numerous ways. Within Berlin, this included, variously, accompanying our interlocutors to other museums and collections, and to communities with which we and or they worked. Nationally and internationally, it involved visits to or from other museums, curators or academics, as well as, in some cases, through tracing the journeys of objects. We were thus almost inevitably confronted by the relational nature of the museums and exhibition-making processes (Gosden et al. 2007). Our field sites - or more specifically, the exhibition-processes with which we began - were, thus, points of departure rather than the boundaries of our work.

\section{Feeling Part of Something}

Nevertheless, despite the distribution of the processes that we looked at beyond the confines of the museum walls or the exhibition teams, both museums and exhibition teams - as well as the to-be-filled architectural container of the Humboldt Forum - were clearly important realities for those with whom we worked, and not just for those working inside them. That is not to say, however, that we can just take them for granted in our analysis. Rather, we need to think about how they came to be felt as realities - how organization-ness was done - and with what consequences.

Although the processes of extending outwards might be seen as dissolving the museum as a 'container', such encounters were typically conducted under the name of the museums. Thus, it was as a member of the Ethnological Museum that Margareta travelled to the Republic of Benin to research objects; or it was under the name of the Museum of Islamic Art that Christine was involved in initiatives with Berlin's 'Muslim communities'. This making of entities through their encounters is a point that has been made many times in anthropology (e.g. Evans-Pritchard 1940). More generally, the fact of being named entities indexed the museums as actors. This is reinforced temporally through their histories, thus also making them feel 'given'. Substantiating them too is the fact that they have specific locations within buildings (though not buildings of their own, and in the case of the EM the display space was closed in January 2018) and also through their association with specific collections.

Despite these relatively obvious markers of being a museum, however, it does not necessarily follow that those who are officially part of one have it as their primary point of identification in their everyday work. Thus, for example, while the possession of ethnological collections is constitutive of the EM, in day-to-day practice curators tend not to refer to them as a collectivity but, rather, talk of specific collections, using names such as 'Africa' or 'South America', or, especially commonly, through possessive terms such as 'my' and 'your' or ' $X$ 's'. Such everyday organizational thinking has consequences for the ways in which activities such as exhibition-making are conducted, with the work for the future Humboldt Forum, in 2013-14 at least, being relatively atomised rather than strongly organised as a collective activity - even while from the outside the EM rather than specific collections was the usual point of reference.

As many scholars who have conducted organizational ethnography also recognize, senses of being part of an organization are also formed through shared organizational activities, such as meetings, and shared affective atmospheres - negative as well as positive (e.g. 
Garsten and Nyquist 2013; Rouleau et al. 2014; Brown et al. 2017). They can be generated or reinforced by shared implicit knowledge - 'unwritten laws and processes' as one new recruit to the EM described it in frustration. In the case of the Berlin exhibition team, which was built from scratch with the purpose of creating the exhibition for the Humboldt Forum, 'team-ness' was partly created through its leader's talk of the dynamic team that he had assembled as well as by shared rituals of group visits and team meetings, which were accompanied by much joking as well as refreshments. Moreover, it was produced through a sense of being engaged in the shared collective enterprise of exhibition-making and, even more so, of battling to do this in the face of a lack of overall clarity - especially at the time the team was established in 2016 - about plans for other parts of the Humboldt Forum, as well as of doing so in innovative (e.g. participative) ways that stood against more conventional approaches.

Organization is, then, also an achievement - something that is 'done' or 'made' - even while it can at the same time be taken for granted in many contexts. Ethnography allows for getting a handle on this. It lets us grasp when, where and how boundaries or connections are created to constitute the museum or other organization in practice, which organizational formations come into play and what then follows from this.

\section{Concluding discussion}

In this article, we have argued for a form of museum ethnography that retains the in-depth critical insight that ethnography can provide while not taking the museum as a taken-forgranted methodological container; and we have presented a research design capable of going beyond containerism in a range of ways. The ongoing Making Differences project is a realization of this research design and in this article we have illustrated the argument for a multi-sited, multi-linked and multi-researcher ethnography by drawing on three fairly advanced (in that they have all entailed over two years' fieldwork) ethnographic sub-projects that are part of it. The overall project, with over ten researchers, is, we believe, the largest such museum ethnographic venture to date. Its work is not restricted to examples from relatively high profile museum developments, or to exhibition-making processes, as we draw on here, but also includes smaller galleries and heritage sites, activist, community and amateur initiatives. It is important to emphasize that the aim here is not to produce some kind of complete or even representative mapping: the methodological model is not that of a jigsaw puzzle or of a tidy kind of organigram. Indeed, some of the sub-projects themselves are already strongly conceived as trans-locational - such as that of Larissa Förster on provenance and colonial heritage, or that of Tahani Nadim on data natures - even while they have specific locational realizations (such as in the collections of the EM or the Berlin Museum of Natural History). Moreover, all of the sub-projects are conceived at least partly beyond single sites (for example, through concerns with how ethnological museums are addressing their legacies or how museums are representing Islam). ${ }^{9}$

What a collective multi-sited, multi-linked and multi-researcher ethnography such as this allows, then, is a more collage-like model in which we are able to investigate phenomena and transformations from a range of locations, emphases and points of view. That variety of perspectives is not restricted to those of the specific groups or developments with which we work but is also a function of their, and our, varied positions within the field. Even among the three of us here there were differences in our own roles and status that gave us access to diverse dimensions of the processes underway. Christine, for example, had long worked in museum education and evaluation, and thus began with extensive knowledge of Berlin's museum system, as well as of community groups and initiatives. She also had an important, shaping role in the initiatives that she studied. So too did Margareta, who worked as a curator's assistant and co-curated an exhibition as part of experiments for deciding on future content for the Humboldt Forum. Sharon, by contrast, participated more as an observer, making less substantial material contributions on a day-to-day level, though she was also part of some more high-level processes through roles such as her membership of the Berlin exhibition's advisory board, and other formal and semi-informal meetings related to the Humboldt Forum and other museum developments. This mix undoubtedly helps us to get a better handle on what is going on - at a variety of levels, settings and positions - as well as prompting us to reflect on our own positionalities. 
Questions about museum organization are highly topical in our Berlin field site. The organigram with which we began, and its lively reception and circulation, is just one illustration of a considerable interest, indeed not restricted to Berlin (as evidenced by the fact that the newspaper in which it appeared is based in South Germany), in the organization of the Humboldt Forum. The reasons for this interest lie partly in the contested history of the site - including the destruction of the GDR's Palace of the Republic - and the symbolism of building a part reconstruction of a Baroque Prussian palace, as well as in concerns about the colonial legacies of the ethnological objects that will be shown there (see Binder 2007, von Bose 2016, Bach 2017). They lie too in awareness of the large number of interested players - and the diverse political positions that some of these occupy - who are involved in producing a substantial new cultural institution in the centre of Berlin, on its UNESCO World Heritage Museum Island. Whether the individual museums - the EM and AKU - will be named in it, or whether they, together with others such as the Berlin Exhibition, will be merged into collective Humboldt Forum content is a current matter of debate. That debate is inherently about organization-making - trying to craft an organization into being, to fill the architectural container that preceded it. Doing so in the face of what are different teams and museums, different designers, and a process that in its earlier stages especially has involved a surprising paucity of interaction between these, is a major organizational challenge. Developments underway as we write, to replace the two separate directors of the EM and AKU by a shared head of collections, and the formerly three-person overall leadership by one person, are attempts to achieve the Federal Minister of Culture and Media's 2017 stated desire to make it 'all of a piece' ('aus einem Guss') ${ }^{10}$.

Precisely what will result from such organizational restructuring remains to be seen, especially so late in a process, with the Humboldt Forum due to open in 2019. What our own work shows is that what happens at ground level - how people feel themselves to be part of something, and what this is - is also crucial to how they work and, therefore, to what will result. That a rhetoric of 'one-ness' is not in itself enough to achieve this is also evident from the claim by the Director General of the SMB that the SMB should be seen as one museum a 'universal museum' - which 'spreads over many different sites'. ${ }^{11}$ Although there are some respects in which this claim does have traction - for example, through some of the shared services - it is also inattentive to the on-the-ground disconnections and even competition between at least some of the constituent parts.

These more usually unattended aspects of organizations are those on which in-depth ethnographic fieldwork can shed light. Methodologically, however, a perspective that considers how organization-ness is done or achieved, is better placed to tackle this than one that takes the organization for granted. Its premise of non-commitment to the givenness of museums as organizations will be able to better attend to how organization-ness is produced and experienced as, say, a heavy weight of the past or as something more fleeting and provisional, as recalcitrant or as something to shape, as porous or relatively island-like.

In conclusion, then, going behind the scenes remains an important methodology for museum research - reaching parts that other methodologies do not. The challenge is to do so while not remaining only within their confines. We need to get off the island as well as see how the island is part of a wider archipelago and sea. In this article we hope to have shown how this can be done through our discussion of developments centred on - but not confined to - Berlin's Museum Island. The research design and project presented here do not provide the only possibility for avoiding methodological containerism without giving up on ethnography. They are, however, we believe, the most extensive and substantial ones to do so to date within the museum field. Our hope is that they will provide impetus for further methodological reflection and innovation in the future.

Received: 31 July 2017 Finally Accepted: 21 May 2018

\section{Acknowledgments}

We are grateful to the Alexander von Humboldt Foundation and the Prussian Cultural Heritage Foundation for funding this research. In our field sites, we thank those who have endured our presence and even made us welcome. We especially thank Paola Ivanov, Peter Junge, Brinda 
Sommer, Paul Spies and Stefan Weber for comments on an earlier draft of this article. We are also grateful to the special issue editors and the three anonymous referees for their criticisms and suggestions. In addition, we express our gratitude to our colleagues in CARMAH, especially the Making Differences project, for further helping us to develop our ideas and for being part of the journey. None of those thanked necessarily agrees with all of the article's contents and we apologise for not having been able to take up all the points suggested but hope to do so, for some at least, in the future.

\section{Notes}

1 All translations from German are our own unless otherwise indicated.

2 Häntzschel, J. (2017), 'Verstrickung als Prinzip', Süddeutsche Zeitung, 20 November 2017, http://www.sueddeutsche.de/kultur/kulturpolitik-verstrickung-als-prinzip-1.3757309 accessed on 10 April 2018.

3 'Inter-organizational' is a term already used in the organization studies literature (e.g. Zilber 2014). It primarily identifies relationships between organisations. Trans- can be said to refer to relationships cutting across them. We have coined the terms exo-organizational and endo-organizational on the basis of kinship theory (exogamous and endogamous referring, respectively, to marrying out or within one's own group). This reflects in part the fact that some of our thinking about organigrams has been shaped by anthropological discussions of visualisations of kinship. As kinship discussion itself makes clear, exo- and endo- are relational categories, each inflecting upon each other. We should also note that although the terms 'organization' and 'institution' are sometimes used interchangeably and although there can be overlap in their application, we find it heuristically useful to follow the convention of using 'institution' to refer to a general stabilized social form and 'organization' to a specific realization (see Hatch 2011; Garsten and Nyquist 2013: 5); in this context, therefore, to use 'institution' to refer to the museum or museums as a generality, and 'organization' for a specific museum (e.g. Berlin's Ethnological Museum) or other organizational entity (e.g. the Prussian Cultural Heritage Foundation).

4 Goffman (1956), Kate Atkinson's novel, Behind the Scenes at the Museum 1997 was also an inspiration.

5 See http://www.carmah.berlin, accessed 10 April 2018.

6 Although the organigram incorrectly says that on the first floor there will be an exhibition of the Berlin City Museum. The formal position is that the director of the City Museums, Paul Spies, has the title and role of 'Chief Curator' of the Berlin Exhibition.

7 A format that Bourdieu suggests became culturally widespread due to property inheritance practices (1977), though which Bouquet (1996) argues has a longer pedigree in tree imagery and the Bible.

8 Extracts from Margareta von Oswald's field diary, 19.08.2014

9 See http://www.carmah.berlin, accessed 10 April 2018.

10 Andreas Abel and Christine Richter (2017), Monika Grütters: "Mehr Geld für Kultur in Berlin". Im Interview spricht Staatsministerin Monika Grütters über die Finanzierung der Berliner Kultur, die Berlinale und das Einheitsdenkmal', Berliner Morgenpost online, 16.04.2017, https://www.morgenpost.de/berlin/article210268697/Monika-Gruetters-Mehr-Geld-fuer-

Kultur-in-Berlin.html, accessed on 12 April 2018. 


\section{References cited}

Atkinson, K. (1997) Behind the Scenes at the Museum, New York: Doubleday.

Bach, J. (2017) What Remains. Encounters with the Socialist Past in Germany, New York: Columbia University Press.

Basu, P. (2011) 'Object diasporas, resourcing communities: Sierra Leonean collections in the global museumscape', Museum Anthropology, 34 (1) 28-42. URL: https:// anthrosource.onlinelibrary.wiley.com/doi/full/10.1111/j.1548-1379.2010.01105.x

Beltrame, T. N. (2015) 'Creating new connections: Objects, people, and digital data at the Musée du Quai Branly', Anuac 4 (2)106-129.

Bhatti, S. (2012) Translating Museums: A Counterhistory of South Asian Museology, Walnut Creek, California: Routledge.

Binder, B. (2007) Streitfall Stadtmitte. Des Berliner Schloßplatz, Vienna: Böhlau.

von Bose, F. (2016) Das Humboldt-Forum. Eine Ethnographie seiner Planung, Berlin: Kulturverlag Kadmos.

Bouquet, M. (1996) 'Family trees and their affinities. The visual imperative of the genealogical diagram', Journal of the Royal Anthropological Institute 2 (1) 43-44. URL: https://www.jstor.org/stable/3034632?seq=1\#page_scan_tab_contents

Bouquet, M. (2012) Museums: A Visual Anthropology, London, New York: Berg Publishers.

(2015) 'Reactivating the Colonial Collection: Exhibition-Making as Creative Process at the Tropenmuseum, Amsterdam' in A.Coombes and R.Phillips (eds) Museum Transformations, 133-156, New York: Wiley-Blackwell.

Bourdieu, P. (1977) Outline of a Theory of Practice, Cambridge: Cambridge University Press.

Brown, H., Reed, A. and Yarrow, T. (eds) (2017) Meetings: Ethnographies of Organizational Process, Bureaucracy and Assembly, Chichester: Wiley-Blackwell.

Bunzl, M. (2014) In Search of a Lost Avant-Garde: An Anthropologist Investigates the Contemporary Art Museum, Chicago: University of Chicago Press.

Cameron, F. (2015) 'The Liquid Museum: New Institutional Ontologies for a Complex, Uncertain World' in A.Witcomb and K.Message (eds) Museum Theory, 345-361, New York: Wiley-Blackwell.

Danziger, D. (2008) Museum. Behind the Scenes at the Metropolitan Museum of Art, Harmondsworth: Penguin.

Debary, O. and Roustan, M. 2017 'A Journey to the Musée du quai Branly: The Anthropology of a Visit', Museum Anthropology 40 (1) 4-17.

URL: https://anthrosource.onlinelibrary.wiley.com/doi/full/10.1111/muan.12127

Domínguez Rubio, F. (2014) 'Preserving the Unpreservable: Docile and Unruly Objects at MoMA', Theory and Society : Renewal and Critique in Social Theory 43 (6) 617-645. URL: https://link.springer.com/article/10.1007/s11186-014-9233-4

Evans-Pritchard, E.E. 1940 The Nuer, Oxford: Clarendon. 
Falzon, M.-A. (ed.) (2016) Multi-Sited Ethnography. Theory, Praxis and Locality in Contemporary Research, London: Routledge.

Fiskesjö, M. (2007) 'The Trouble with World Culture: Recent Developments in Sweden'. Anthropology Today, 23(5): 6-11. URL: https://onlinelibrary.wiley.com/doi/ abs/10.1111/j.1467-8322.2007.00535.x

Förster, L. and Stoecker, H. (2016) Haut, Haar und Knochen koloniale Spuren in naturkundlichen Sammlungen der Universität Jena, Kromsdorf: VDG Weimar.

Franklin, A. (2014) The Making of MONA, Melbourne: Penguin.

Gable, E. (2013) 'Ethnographie: Das Museum als Feld.' in J. Baur (ed) Museumsanalyse: Methoden und Konturen eines neuen Forschungsfeldes, 55 - 63, Bielefeld: Transcript.

Garsten, C. and A.Nyquist (2013) 'Entries: engaging organisational worlds', in C.Garsten and A.Nyquist (eds) Organisational Anthropology: Doing Ethnography in and among Complex Organisations, 1-25, Cambridge: Pluto.

Geertz, C. (1998) 'Deep hanging out', The New York Review of Books, 45 (16), 69.

Goffman, E. (1956) The Presentation of Self in Everyday Life, New York: Random House.

Gosden, C., Larson, F. and Petch, A. (2007) Knowing Things: Exploring the Collections at the Pitt Rivers Museum, 1884-1945, Oxford; New York: Oxford University Press.

Grande, L. (2017) Curators. Behind the Scenes of Natural History Museums, Chicago: Chicago University Press.

Gupta, A. and Ferguson, J. (1997) Anthropological Locations: Boundaries and Grounds of a Field Science, Berkeley: University of California Press.

Handler, R. and Gable, E. (1997) The New History in an Old Museum: Creating the Past at Colonial Williamsburg, Durham: Duke University Press.

Hatch, M.J. (2011) Organizations: A Very Short Introduction, New York: Oxford University Press.

Hendry, J. (2005) Reclaiming Culture: Indigenous People and Self-Representation, Palgrave Macmillan.

Jung, Y. (2015) 'Micro examination of museum workplace culture: how institutional changes influence the culture of a real-world art museum', Museum Management and Curatorship 31(2) 159-177. URL: https://www.tandfonline.com/doi/abs/10.1080/0964 $\underline{7775.2015 .1117393}$

Katriel, T. (1997) Performing the Past: A Study of Israeli Settlement Museums, London, New York: Routledge.

Kendzia, V.B. (2017) Visitors to the House of Memory: Identity and Political Education at the Jewish Museum Berlin, Oxford, New York: Berghahn Books.

Knudsen, L.V. (2016) 'Participation at Work in the Museum', Museum Management and Curatorship 31 (2) 193-211. URL: https://www.tandfonline.com/doi/abs/10.1080/096 $\underline{47775.2016 .1146916}$ 
Kopytoff, I. (1986) 'The cultural biography of things : commoditization as process' in A. Appadurai (ed) The Social life of things: commodities in cultural perspective, 64-91, Cambridge; New York: Cambridge University Press.

Kreplak, Y. (2017) 'Voir une œuvre en action. Une approche praxéologique de l'étude des œuvres', Cahiers du CAP 5: 189-213.

Krmpotich, C. and Peers, L. (2013) This Is Our Life: Haida Material Heritage and Changing Museum Practice, Vancouver, BC, Toronto: UBC Press.

Lima, M. (2011) Visual Complexity: Mapping Patterns of Information, New York: Princeton Architectural Press.

Macdonald, S. (2002) Behind the Scenes at the Science Museum, Oxford; New York: Berg.

Macdonald, S. (2009) Difficult Heritage. Negotiating the Nazi Past in Nuremberg and Beyond, London: Routledge.

Macdonald, S. (2016) 'New Constellations of Difference in Europe's 21st-Century Museumscape', Museum Anthropology 39 (1) 4-19. URL: https://anthrosource. onlinelibrary.wiley.com/doi/full/10.1111/muan.12104

Mangione, G. (2016) 'Making sense of things: constructing aesthetic experience in museums and galleries', Museum and Society 14(1) 33 - 51. URL: https://www108. lamp.le.ac.uk/ojs1/index.php/mas/article/view/624

Marcus, G. (1998) Ethnography through Thick and Thin, Princeton, NJ: Princeton University Press.

(2012) 'The legacies of Writing Culture and the near future of the ethnographic form: a sketch', Cultural Anthropology 27(3) 427-445. URL: https://anthrosource. onlinelibrary.wiley.com/doi/full/10.1111/j.1548-1360.2012.01152.x

Marsh, D.E. (2016) 'Trace Ethnography, Affect, and Institutional Ecologies in the Distributed Records of a Plaster Model', Museum Anthropology 39 (2) 111-129. URL: https:// anthrosource.onlinelibrary.wiley.com/doi/full/10.1111/muan.12119

McCosker, A. and Wilken, R. (2014) 'Rethinking "Big Data” as Visual Knowledge: the Sublime and the Diagrammatic in Data Visualisation', Visual Studies 29 (2) 155-164. URL: https://www.tandfonline.com/doi/abs/10.1080/1472586X.2014.887268

Meyer, M. (2008) 'On the boundaries and partial connections between amateurs and professionals', Museum and Society, 6 (1) 38-53. URL: https://www108.lamp.le.ac. uk/ojs1/index.php/mas/article/view/111

Miller, D. (1997) Capitalism: an Ethnographic Approach, Oxford: Berg.

Morgan, J. (2013) 'Examining the "Flexible Museum”: Exhibition Process, a Project Approach, and the Creative Element', Museum and Society 11 (2) 158-171. URL: https://www108.lamp.le.ac.uk/ojs1/index.php/mas/article/view/230

Morse, N. and Munro, E. (2015) 'Museums' Community Engagement Schemes, Austerity and Practices of Care in Tw o Local Museum Services', Social \& Cultural Geography 19 (3) 1-22. URL: https://www.tandfonline.com/doi/abs/10.1080/14649365.2015.10 $\underline{89583}$

O'Hanlon, M. (1993) Paradise: Portraying the New Guinea Highlands, London: British Museum Press. 
Oswald, M. von and Rodatus, V. (2017) 'Decolonizing Research, Cosmo-optimistic Collaboration?: Making Object Biographies', Museum Worlds 5 (1) 211-223. URL: https://www.berghahnjournals.com/abstract/journals/museum-worlds/5/1/ armw050117.xml

Porsché, Y. (2018) Public Representations of Immigrants in Museums: Exhibition and Exposure in France and Germany, New York: Palgrave Macmillan.

Price, S. (2007) Paris Primitive: Jacques Chirac's Museum on the Quai Branly, Chicago: University of Chicago Press.

Riles, A. (ed.) (2006) Documents: Artifacts of Modern Knowledge, Ann Arbor: University of Michigan Press.

Roberts, L.C. (1997) From Knowledge to Narrative: Educators and the Changing Museum, Washington, D.C.: Smithsonian Institution Press.

Rouleau, L., Rond, M. de and Muscam, G. (2014) 'From the Ethnographic Turn to New Forms of Organizational Ethnography', Journal of Organizational Ethnography 3 (1) 2-9. URL: https://www.emeraldinsight.com/doi/abs/10.1108/JOE-02-2014-0006

Sabeti, S. (2018) Creativity and Learning in Later Life: An Ethnography of Museum Education, London: Routledge.

Schmitt, S.B. (2012) Ein Wissenschaftsmuseum geht unter die Haut: sensorische Ethnographie des Deutschen Hygiene-Museums, Bielefeld: Transcript.

Schorch, P., McCarthy, C. and Hakiwai, A. (2016) ‘Globalizing Māori Museology: Reconceptualizing Engagement, Knowledge, and Virtuality through Mana Taonga', Museum Anthropology 39 (1) 48-69. URL: https://anthrosource.onlinelibrary.wiley. com/doi/full/10.1111/muan.12103

Shannon, J.A. (2014) Our Lives: Collaboration, Native Voice, and the Making of the National Museum of the American Indian, Santa Fe, NM: School for Advanced Research Press.

Smith, R. (2007) The Museum. Behind the Scenes at the British Museum, London: BBC Books.

Strathern, M. (1996) 'Cutting the network', Journal of the Royal Anthropological Institute 2 (3) 517-535. URL: https://www.jstor.org/stable/3034901?seq=1\#page scan tab contents

Torres, A. M. (2011) 'The Museumization of Migration in Paris and Berlin and Debates on Representation', Human Architecture: Journal of the Sociology of Self-Knowledge 9

(4) 5-21. URL: https://search.proquest.com/openview/c08fea8d2866a6c119477a819 27ebb30/1?pq-origsite $=$ gscholar \&cbl=40294

Tythacott, L. (2011) The Lives of Chinese Objects: Buddhism, Imperialism and Display, New York: Berghahn Books.

Watson, T.J. (2011) 'Ethnography, reality, and truth: the vital need for studies of 'how things work' in organizations and management', Journal of Management Studies, 48 (1) 202-217. URL: https://onlinelibrary.wiley.com/doi/full/10.1111/j.1467$\underline{6486.2010 .00979 . x}$

Wimmer, A. and Glick Schiller, N. (2002) 'Methodological Nationalism and Beyond: Nationstate Building, Migration and the Social Sciences', Global Networks 2 (4) 301-334. URL: https://onlinelibrary.wiley.com/doi/abs/10.1111/1471-0374.00043 
Winter, S., N.Berente, J.Howison, B.Butler (2014) 'Beyond the organizational "container": conceptualizing $21^{\text {st }}$ Century sociotechnical work', Information and Organization, 24, 260-259. URL: https://www.sciencedirect.com/science/article/pii/ $\underline{\mathrm{S} 1471772714000311}$

Yaneva, A. (2012) 'Der Aufbau von Installationen. Eine Pragmatische Annäherung an Kunst', Zeitschrift für Ästhetik und Allgemeine Kunstwissenschaft 57 (1) 150-171.

Yanow, D., Ybema, S. and Van Hulst, M. (2012), 'Practising organizational ethnography', in Symon, G. and Cassell, C. (eds), The Practice of Qualitative Organizational Research: Core Methods and Current Challenges, 331-350, Sage, London.

Ybema, S., Yanow, D., Wels, H. and Kamsteeg, F.H. (2009), 'Studying everyday organizational life', in Ybema, S., Yanow, D., Kamsteeg, F.H. and Wels, H. (eds), Organizational Ethnography: Studying the Complexity of Everyday Life, 1-20, Sage, London.

Zilber, T.B. (2014) 'Beyond a Single Organization: Challenges and Opportunities in Doing Field Level Ethnography', Journal of Organizational Ethnography 3 (1) 96-113. URL: https://www.emeraldinsight.com/doi/abs/10.1108/JOE-11-2012-0043

\author{
Authors \\ Sharon Macdonald, Christine Gerbich, Margareta von Oswald \\ Humboldt-Universität zu Berlin \\ Institut für Europäische Ethnologie \\ Centre for Anthropological Research on Museums and Heritage \\ Mohrenstr. 40/41 \\ 10117 Berlin \\ Email: sharon.macdonald@hu-berlin.de; Phone +49 30209370860 \\ Email: christine.gerbich@hu-berlin.de; Phone +49 30209370886 \\ Email: margareta.von.oswald@hu-berlin.de; Phone +49 30209370886
}

*Sharon Macdonald is Alexander von HumboldtProfessor of Social Anthropology in the Institute of European Ethnology, Humboldt-Universität zu Berlin and Anniversary Professor of Cultural Anthropology at the University of York. In Berlin, she established and directs CARMAH, the Centre for Anthropological Research on Museums and Heritage. This includes the research project Making Differences: Transforming Museums and Heritage in the $21^{\text {st }}$ Century, which is funded primarily by the Alexander von Humboldt Foundation. She also leads the Contentious Collections work-package of the Horizon 2020 TRACES (Transmitting Contentious Cultural Heritage with the Arts) project, and the Profusion theme of the AHRC Heritage Futures project. Her authored books include Behind the Scenes at the Science Museum (2002), Difficult Heritage (2009) and Memorylands (2013).

${ }^{* *}$ Christine Gerbich is a researcher at the Centre for Anthropological Research on Museums and Heritage (CARMAH), Berlin. She studied sociology, German philology and Media Studies in Berlin and Bloomington, Indiana. She has worked on several national and international research projects in the field of evaluation, including The Museum Laboratory. On Curating Islamic Arts and Cultural Histories between 2009 and 2013. Her PhD project is an ethnography of the futurability of the Museum of Islamic Art in Berlin where she was involved in two projects: an interdisciplinary research project to develop the exhibition The Heritage of the Old Kings. Ctesiphon and the Persian Sources of Islamic Art and the collaborative project TAMAM - the Mosque Communities' education project with the Museum für Islamische Kunst. Her research 
interests include the interactions between museums and civic society, collaborative learning, visitor research methodologies, decolonizing practices and future-making.

${ }^{* * *}$ Margareta von Oswald is a researcher at the Centre for Anthropological Research on Museums and Heritage (CARMAH), Berlin. She studied anthropology and social sciences in Bordeaux, Stuttgart and Paris. For her PhD-project (École des Hautes Études en Sciences Sociales Paris; Humboldt-Universität zu Berlin), she analyzes the 'making of' of the future permanent exhibitions for Berlin's Humboldt Forum, and Tervuren's Royal Museum of Central Africa, that she contributed to and observed from 2013-2015. In 2015, she co-curated the exhibition Object Biographies with Verena Rodatus (Humboldt Lab Dahlem). Her research interests include the negotiations of colonial pasts in the present, museum ethnographies, curatorship, and collections acquired on the African continent. 